20th-century smugglers use

bydney

IN a cloak and dagger operation that could have been lifted from the pages of a spy thriller, a group of wily Australians have combined the traditional trickery of smuggling with high-technology embryo implantation techniques to try to break South Africa's near-monopoly of the $\$ 200$ million market for mohair wool.

Mohair wool comes from angora goats, the finest of which are bred in South Africa. Exporting them without the permission of the South African National Angora Breeding Society is banned. But in 1986, three Australian farmers raised $\mathrm{A} \$ 600,000$ from Australian goat breeders to try to lay their hands on a herd.

In South Africa they succeeded in buying 269 top quality Angora and Boer (meat) goats. Waiting until Christmas Eve, when they guessed official diligence would be low, they loaded the herd into trucks and set off at night for a 47-hour trip to the border with Zimbabwe. One farmer flew ahead of the convoy in an aeroplane, smoothing out paperwork at more than 20 checkpoints along the way. At the border, customs inspectors were persuaded the trucks contained sheep rather than goats, a move one of the men involved in the trip agreed was "against the spirit of the South African angora industry regulations".

In Zimbabwe, the Australians bred the goats and collected almost 400 embryos which were frozen and flown to the Australian Government offshore quarantine station on the Cocos Islands in the Indian Ocean. The plan was to implant the embryos into surrogate mothers on the Cocos Islands and keep the kids in quarantine. But the original partnership broke up and the frozen embryos were instead sold to Embyrotech, a Western Australian company. Embryotech transported the frozen embryos to New Zealand, which has already built up a herd of 74 Angora kids and 24 Boer kids.

With multiple ovulation and embryotransfer technology, the number of offspring can be rapidly increased. Once seven years of quarantine are up - essential to ensure the herd is free from the scrapie disease agent - Embryotech has just announced that it will sell all the offspring to Australian farmers, giving them a chance to cash in on the lucrative angora wool market.

Three other angora herds have also been 'imported' to New Zealand from South Africa. In 1987 South Africa introduced legislation that allows the government to confiscate the farm of anyone collaborating in illegal exports.

\title{
A certain uncertainty awaits in Washington's new year
}

\section{Washington}

Celestial mechanics guarantees that in August this year the Voyager space probe will make a historic encounter with the outer planet Neptune. But apart from that, nearly every other scientific endeavour of 1989 is tinged by an uncertainty not felt for 8 years: from 20 January a new man will be in the White House, and although President-elect George Bush is of the same political cloth as his predecessor, there are already indications that new priorities can be expected.

During his campaign for election, Bush promised to raise the status of the White House science adviser to the rank of presidential assistant, but by the year's end when - nearly - all cabinet appointments had been announced there was still no word about who will fill that new position. This may be an indication that science will not in fact receive its promised new importance, but it could just as easily be evidence that Bush has found - as have others before him - that the political and bureaucratic complexities of bringing in a new team can foil the best intentions.

Adding to the uncertainty are a spate of new faces in important congressional appropriations committees. This month, Congress will receive the 1990 budget blueprint prepared by the Reagan administration, but that will certainly be modified by both the Bush administration and Congress before the start of the new fiscal year.

In addition to establishing budget priorities that could spell the end of big science projects such as the Superconducting Super Collider - now scheduled to make Waxahachie, Texas the mecca of the high energy physics world - and the National Aeronautics and Space Administration (NASA)'s Space Station, Congress will also continue to grapple with the issue of scientific misconduct.

The arcane question of the specificity of the Bet-1 reagent may be the central theme of hearings scheduled for early in the year, as a powerful committee led by Representative John Dingell (Democrat, Michigan) resumes its inquiry into a paper appearing in Cell co-authored by, among others, Nobel laureate David Baltimore, that has raised complicated issues of how the propriety of scientific data should be investigated. Another committee chaired by Representative Ted Weiss (Democrat, New York), will continue hearings probing conflict-of-interest issues for scientists who work at academic institutions but are supported by private industry.

For NASA, 1988 was a good year, and 1989 promises to be even better. The space shuttle returned to service in Sep- tember, and a second successful flight followed. Three major scientific missions are scheduled for launch this year; the Magellan Venus radar mapper, the Galileo mission to Jupiter and the Hubble Space Telescope. If, however, the Bush administration decides not to go forward with the space station, NASA will be searching for a new identity, as military and commercial space activities have already been moved elsewhere.

NASA will certainly have a role studying the environment, a topic that will occupy centre stage in 1989. Last summer's drought and heat wave convinced many that greenhouse warming was worth serious study, and finding ways to limit the production of greenhouse gases, including renewed consideration of nuclear power, will be a constant theme.

If new commercial nuclear reactors are still some way off, the Department of Energy must nevertheless finalize plans for a new defence production reactor to restore US capacity to produce tritium and plutonium for nuclear weapons. By the end of 1988, all US reactors capable of producing tritium had been shut down, and a constant stream of newly discovered threats to safe operation of the ageing reactors threatened any early restart.

The National Science Foundation (NSF) is still hoping to see its budget double by 1992 , an increase promised by the last administration, but probably out of reach. NSF has moved ahead by providing money for 11 new science and technology centres, and more may be authorized in 1989.

Coping with AIDS will continue to be a major preoccupation of the US Public Health Service and its subordinate National Institutes of Health (NIH) in Bethesda and Centers for Disease Control in Atlanta. Also in Bethesda, the NIH human genome office, led by James Watson, will get into full swing next year, and W. French Anderson, along with colleague Steven Rosenberg, should begin the first-ever experiment involving the introduction of genetically engineered cells into human subjects.

Biomedical research will continue to face stiff challenges from two wellorganized lobbies. Animal rights activists will continue to push for restrictions on the use of animals in research, and antiabortion groups will seek to prohibit the use in research of fetal tissue from induced abortions. But Bush's choice of Louis Sullivan for Secretary of Health and Human Services has at once outraged anti-abortion lobbies and proved that what was past is not necessarily prelude.

Joseph Palca 